\title{
119 渦輪督造のジェット騒音に及ぼす影響
}

近畿大工児島忠倫, 近畿大工 島津江麻里 ${ }^{\circ}$ 近畿大理工 松岡祥浩, 東洋アルミ 楠井 潤

\section{Effect of Structure of Vortex Rings on Jet Noise}

\author{
Tadatomo KOJIMA *, Mari SHIMAZUE *, \\ Yoshihiro MATSUOKA ${ }^{* *}$ and Jun KUSUI ${ }^{* * *}$
}

In this report, it was discussed by the digital image processing that the characteristics of the discrete frequency noise for subsonic jets were closely related to the structure and behavior of vortex rings. The vortex rings released from nozzle with exit divergent angle were visualized by Schlieren method or a high-speed video camera included its system. It was clarified that the interaction of vortex rings were classified into phenomena of chasing, merging and rolling up and so on, and those phenomena had characteristic frequency distributions of noise respectively.

\section{1. 緒言}

離散周波数を伴った低速ジェットに生じる空力音響特性は，フィードバック機構 (1) の 存在により論じられているが(2)(3)，渦輪の構造や挙動も密接に関連していると思われる. 円形シェット中の渦輪の成長から崩壊に至る過程での挙動に関する研究では，合体現象や ロールアップ現象についての報告 ${ }^{(4)}{ }^{(5)}$ が見られる。しかしながら, 騒音特性と渦輪構造 が相互に及ぼす影響について明確にした研究例はほとんどない，本研究は，種々の出口広 がり角度をもつノズルから静止大気中へ連続して噴出される亜音速および要音速シェット について，可視化および画像処理により渦輪構造を分析し，渦輪同士の千涉の違いが，離 散周波数騒音（ディスクリート音）の周波数分布に及ぼす影響について明らかにしたもの である(6).

\section{2. 実験装置およひ方法}

ノズルは, 全長 $46 \mathrm{~mm}$, 内径 $9.2 \mathrm{~mm}$ のストレート管に $\theta=10^{\circ}, 15^{\circ}, 20^{\circ}, 25^{\circ}, 30^{\circ}$ の出 口広がり角度を設けたものを使用した．実験は，よどみ压力 $P o$ と大気压 $P a$ との比 $P o / P a$ が $6.0 \times 10^{-3} \sim 1.0$ 範囲で行っている./ズルから周期的に放出される渦輪は，シュリ ーレンシステムに組み込んだハイスピードビデオカメラ（記録速度：40,500こま/ sec，フ レームインターバル: 約 $25 \mu \mathrm{s})$ で連続撮影され，その構造之挙動が，画像処理によって調 べられた。なお，渦輪間の距離や移流速度の計測には, 約 $50 \sim 70$ フレームの 2 值化画像 を用いている。

\section{3. 実験結果および考察}

$3 \cdot 1$ 渦輪の合体現象 Fig.1(a)〜 (d)に, $\theta=15^{\circ}$ のノズルから压力比 $\mathrm{Po} / \mathrm{Pa}=0.600$ で放出された渦輪のノズル出口付近での挙動を示す。なお，これらは，画像処理によって

\footnotetext{
'Department of Mechanical Systems Engineering, Faculty of Engineering, Kinki University, Umenobe, Takaya, Higashihiroshima, 739-2I, ,Japan - Department of Mechanical Engineering, Faculty of Science and Technology, Kinki University, Kowakae 3-4-1, Higashi Osaka, 577, Japan ***Toyo Aluminium K.K, Aioicyo 4-1, Yao, Osaka 581, Japan
} 
画質改善された鮮鋭化画像である. Fig.1 (a)に示すように，ある時刻において噴 出直後の第 1 渦輪とその下流側に先行 する第 2 渦輪がそれぞれ観察される. 時間の経過に伴って第 1 渦輪は, Fig.1(b), (c) に示すように第 2 渦輪に接 近し, やがて Fig.1(d) に示すように二つ の渦輪は合体する。Fig.1には見られな いが, 27,000こま/secで撮影した画像 では, 第 1,2 渦輪の下流に合体渦輪 が先行する渦輪構造となっている. そ して, 第 $1 ， 2$ 渦輪が新たに合体する 前に, 合体渦輪は消滅する傾向にある. このような渦輪の合体現象は, $\theta=15^{\circ}$ のノズルのディスクリート音の発生し たすべての場合に見られた．

Fig. 2 に, $\theta=15^{\circ}, \quad P o / P a=0.628$ に おけるディスクリート音のパワースペ クトルを示す. 基本周波数の第 1 ピー クと高周波成分に音圧レベル SPLの高 い数個のピークが発生している.また, 第 2 ピークは第 3 ピークよりも低い. 多くの可視化写真や 2 值化処理画像少 ら, 渦輪の合体現象が見られる場合に は, Fig.2に示すような高周波数側で鋭 いピーク群の発生する離散周波数分布 になりやすいことがわかった．また， 第 2 ピークは, 圧力比の増大につれて, 消隇する傾向にある.

Fig.3に, $\theta=15^{\circ}, \quad P o / P a=0.597$ の 渦輪の移流速度 $U \omega \omega$ の分布を示す. 渦輪 の移流速度は, 2 值化画像から渦輪の重心位置の移動距離を求めることにより算出した. なお, 横軸の $X / d$ は, ノズル出口から噴出方向への水平距離をノズル内径で無次元化した ものである，第 1 渦輪は, 先行する第 2 渦輪に誘引されて崩壊, 消隇する $X / d=1$ 付近ま でほぼ直線的に加速している。第 2 渦輪の移流速度は, 約 $100 \mathrm{~m} / \mathrm{s}$ とかなり低いが, 1.5 $\lesssim X / d \lesssim 2$ で第 1 渦輪と合体して速度エネルギーが増大するために, 合体渦輪の移流速度 は，約 $150 \mathrm{~m} / \mathrm{s}$ 付近まで上昇する傾向にある.

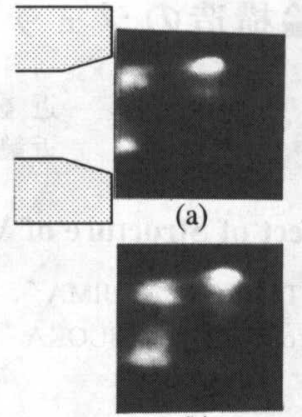

(b)

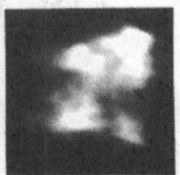

(c)

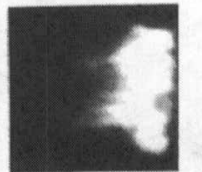

(d)
Fig.1 Merging phenomenon of vortex rings, $\theta=15^{\circ}, \mathrm{Po} / \mathrm{Pa}=0.600$

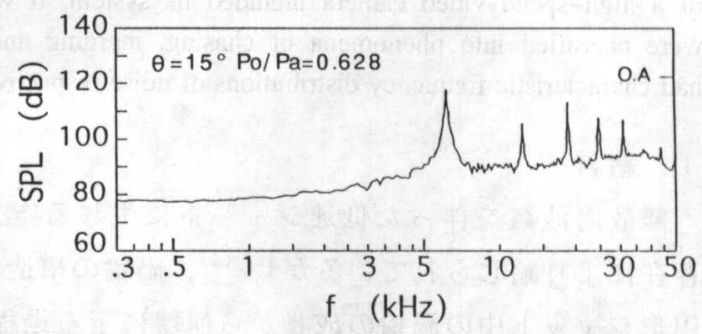

Fig.2 Frequency spectrum of jet noise, $\theta=15^{\circ}, \mathrm{Po} / \mathrm{Pa}=0.628$

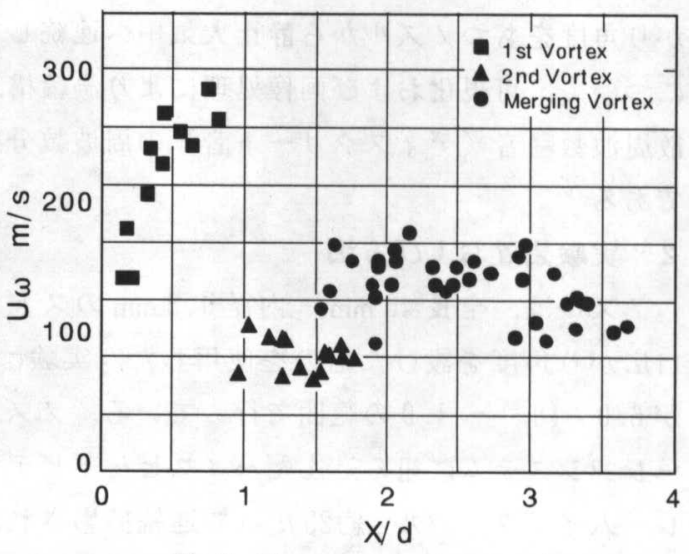

Fig.3 Phase speed of vortex rings, $\theta=15^{\circ}, \mathrm{Po} / \mathrm{Pa}=0.597$ 
Fig. 4 に, $\quad \theta=15^{\circ}, \mathrm{Po} / \mathrm{Pa}=0.597$ に おりる第 $1 ， 2$ 渦輪の重心までの無次 元距離 $X_{1} / d, X_{2} / d$ と無次元化した渦 輪間の距離 $\lambda_{\omega} / d$ の分布を示す. 第 1 渦輪と第 2 渦輪間の距離は, 合体現象 のために，下流方向にいくにつれて減 少しており， $\lambda_{\omega} / d=0$ 上にある合体 渦輪は, $1.5 \lesssim X_{1} / d \lesssim 2$ の範囲に存在 している、第 2 渦輪と合体渦輪間の距 離は, $\lambda_{\omega} / d \approx 2 \sim 2.5$ と比較的大き いために, 渦輪同士の干渉はほとんど ないものと思われる。なお， Fig. 1およ び Fig. 4 で示した渦輪の合体位置は, 圧力比の増大に伴って上流方向へ移動 する傾向にある.

3. 2 渦輪の追跡現象 Fig.5(a) (d)に, $\theta=10^{\circ}$ のノズルから圧力比 $\mathrm{Po} / \mathrm{Pa}=0.462$ で放出された渦輪の) ズル出口付近での挙動を示す.なお, これらは, 画質改善後の濃淡画像に 2 値化処理を行ったものである. Fig. 5(a) に示すように，ある時刻においてノズ ル出口部の第 1 渦と, その下流側に先 行する第 2 渦がそれぞれ観察される. 時間の経過に伴って, 第 1 渦輪が Fig. 5 (b), (c) に示すように第 2 渦輪に接近す るため, 二つの渦輪間距離は狭まるが, 次の瞬間には, 第 1 渦輪は, Fig. 6(d) のように第 2 渦輪の上流側で消隇する. この場合, 二つの渦輪に合体は生じない。このような渦輪の追跡現象は, $0.46 \lesssim P o / P a$ $\lesssim 0.63$ で観察され，第 1 渦輪が消滅する位置は $X / d \approx 0.9$, そのときの第 2 渦輪の位置は $X / d \approx 1.5$ となった.

Fig. 6 に $\theta=10^{\circ}, P o / P a=0.502$ におけるディスクリート音のパワースペクトルを示す. 基本周波数の第 1 ピークと $30 \mathrm{kHz}$ 付近のピークの間に, 音圧レベル SPLの低いピーク成 分がいくつか現れている．渦輪の追跡現象が見られる騒音のスペクトルは，Fig.6のよう な離散周波数分布になる傾向がある.これは, 第 1 渦輪すなわち追跡渦輪が先行渦輪と合 体する前に消隇するために, 渦輪同士の干渉が弱くなることに起因していると思われる. 


\section{$3 \cdot 3$ 渦輪のロールアップ現象}

Fig.7, Fig.8に, $\theta=10^{\circ}$ のノズルの圧力 比 $\mathrm{Po} / \mathrm{Pa}=0.746$ と $\theta=30^{\circ}$ のノズルの 圧力比 $\mathrm{Po} / \mathrm{Pa}=0.282$ における瞬間的な 流れの可視化写真（せん光時間 $1 \mu \mathrm{s}$ ) を示す. 第 1 渦輪のすぐ下流側で主流 が絞られ，渦輪が急激に巻き上げられ るロールアップ現象が見られる.

Fig.9に, $\quad \theta=30^{\circ}, \quad P o / P a=0.296$ に おけるディスクリート音のパワースペ クトルを示す. 基本周波数に狭帯域の 鋭いピークをむつ分布となっている. 渦輪のロールアップ現象が見られる $\theta$ $=10^{\circ}, 30^{\circ}$ のある圧力比の範囲では, Fig.9に示すような狭帯域で単一ピーク をむつ高調波成分の発生しにくい離散 周波数分布となる傾向がある.これは, ロールアップ現象のために, 渦輪の干 渉が弱くなることに起因しているもの と思われる.

\section{4. 結言}

出口広がり角度が $10^{\circ} \sim 30^{\circ}$ のノズルから亜音速および遷音速で噴出されるジェットに ついて, 離散周波数騒音特性と渦輪構造の挙動が相互に及ぼす影響を可視化と画像処理に よって調べ, 以下の知見を得た.

（１）噴流中の渦輪構造を渦輪の干渉の違いにより，合体現象，追跡現象，ロールア

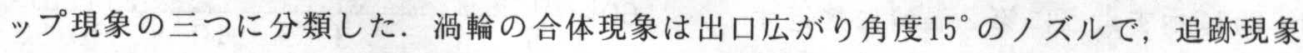

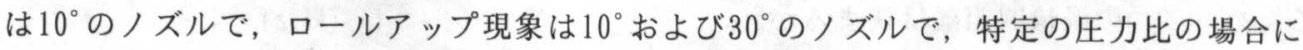
観察された.

（２）渦輪の合体現象，追跡現象，ロールアップ現象が発生する場合のディスクリー 卜音の離散周波数は，それぞれの現象に特有の分布となる.

\section{文 献}

( 1 ) Powell, A., Proc. Phys. Soc. Am., 66B(1953), 1039-1056.

（２）倉澤・小幡・平田・笠木，機論，53-488， B(1987), 1254-1260.

(3) 朴・望月・木谷, 機論, 59-565, B(1993), 2756-2761.

( 4 ) Hussain, A. K. M. F. , J. Fluid Mech., 173(1986), 303-356.

（5）栗間・宮本・笠木・平田，機論，60-574， B(1994), 2007-20130.

（6）览島・楊・島津江・松岡，機論，61-585, C(1995), 1804-1809. 